\title{
First Asian record of Comatricha anomala, a rare epiphytic corticolous myxomycete
}

\section{Anastasia Vlasenko ${ }^{1 *}$, Vyacheslav Vlasenko ${ }^{{ }^{*}}$}

${ }^{1}$ Central Siberian Botanical Garden, Siberian Branch, Russian Academy of Sciences, Zolotodolinskaya, 101, Novosibirsk, RU-630090

* Corresponding author:

vlasenkomyces@mail.ru

Keywords: Stemonitidales, epiphytic myxomycetes, moist chamber culture, SEM, new records.

\section{Article info:}

Received: 01 February 2019

Accepted: 03 June 2019

Published online: 06 May 2020

Corresponding Editor: Riikka Linnakoski

\begin{abstract}
The Corticolous Myxomycetes comprise a group of slime-moulds that grow primarily on the bark of living trees. This work presents the first records of $\mathrm{Co}$ matricha anomala in Asia with data on its localities, habitat, and distribution. Comatricha species commonly inhabit bark folds of living trees, occasionally other substrates. Of the approximately 36 species in the genus, 13 have been recorded in Asia. Comatricha anomala was previously known only from Europe, North America and Cuba. Comatricha anoma$l a$ were isolated using the moist-chamber method, which is a highly efficient means to identify hidden diversity of myxomycetes. Sporocarps of C. anomala were found in Petri dishes while examining a bark obtained from living Pinus sylvestris from the Novosibirsk Region. C. anomala differs from other species of Comatricha in its unique spore ornamentation. Scanning electron microscopy necessary to characterize the ornamentation of the surface of the spores in the Comatricha genus. The work includes a revised description of $C$. anomala with a scanning electron micrograph study of the spore ornamentation.
\end{abstract}




\section{Introduction}

The Stemonitidaceae is a species-rich family of Myxomycetes. Since Elias Magnus Fries established this family in 1829, 19 genera and 239 species have been reported worldwide, of the total approximate 900 described species of Myxomycetes (Lado 20052018, Fiore-Donno et al. 2012). This family is characterized by the dark-colored spore mass, a capillitium consisting of smooth, dark threads, a prominent columella, the absence of lime deposits in all parts of the fruiting body, and sporangiate and stipitate fruiting bodies; yet sessile sporangia, aethalia, pseudoaethalia or plasmodiocarps are occasionally encountered.

Comatricha was established by Preuss in 1851, with C. obtusata as the type for the genus. Based on SSU rDNA, the majority of Comatricha species comprise a clade sister to Stemonitis (Fiore-Donno et al. 2008, 2012). Of the approximately 36 species in the genus, 13 have been recorded in Asia. Comatricha alta, C. elegans, C. laxa, C. nigra, C. pulchella, C. tenerrima were found in Japan and the Asian part of Russia; C. brachypus, C. kowalskii, C. filamentosa, $C$. fragilis, $C$. parvispora were found only in Japan; $C$. ellae and C. rigidireta were found only in the Asian part of Russia. Most of the Comatricha species in the Asian part of Russia are found in the south of Western Siberia (Novozhilov et al. 2009, 2010, Vlasenko \& Novozhilov 2011, Vlasenko 2013, Vlasenko et al. 2013a,b, 2016, GBIF 2019).

The genus Comatricha is characterized by globose or ovate sporocarps. The stalk of the sporocarp is fibrous and usually solid. However, if it appears hollow, then fibrous and opaque capillitium arises from the whole length of the columella. It rarely forms a surface net and free ends may be present. The morphologically-similar genera Stemonaria and Stemonitis are characterized by sporocarps without a fibrous stalk, and in Stemonitopsis the stalk is fibrous only at the base. In some species of Stremonar$i a$, the capillitium has long free ends and arises from the whole length of the columella, forming an internal net but no surface net. In Stemonitis, the capillitium forms a closed surface net, which can sometimes break away from the internal net. Free ends are more often absent, and when present, they are very short, spinulose, and emerge from the surface net. In Stremonitopsis, the capillitium arises from the whole length of the columella, forming an internal net of large mesh and a fragmented small-meshed surface net. Free ends are more often absent, and when present, they are very short and extend from the surface net.

Species within the genus Comatricha are distinguished by complex morphological features (Table 1). Scanning electron microscopy may be necessary to characterize the ornamentation of the surface of the spores. The stalk of the sporocarp of $C$. anomala is fibrous, usually solid, and occasionally may appear hollow, but is always fibrous and opaque. The capillitium of C. anomala arises from the whole length of the columella, rarely forms a surface net, and has long free ends.

Comatricha species commonly inhabit bark folds of living trees, bark and wood of dead trees, litter, and occasionally other substrates. Samples with large sporocarps can be collected in the field. To identify species with small sporocarps, a commonly-used technique is the moist-chamber method, which is a highly efficient means to identify hidden diversity of epiphytic myxomycetes (Härkönen \& Ukkola 2000). The use of this technique on living tree bark by Gilbert and Martin (1933) led to the discovery of many new or rare species of myxomycetes from this corticolous habitat.

In addition to reporting the first record of $C$. anomala in Asia, this paper presents detailed morphological, ecological and geographical data on this species. This species is described and illustrated below.

\section{Materials and Methods}

\section{Slime molds isolation}

Comatricha anomala presented here were isolated using the moist-chamber method. Sporocarps of C. anomala were found in three Petri dishes while examining a bark collection obtained from living Pinus sylvestris, growing in the Novosibirsk Region. Bark pieces cut from a living tree at a height of 1.5 meters were placed into Petri dishes on filter paper in a single layer. Traditional methods call for the substrate to the soaked $24 \mathrm{~h}$, with incubation at room temperature after the excess water is poured off (Härkönen 1977). In this study, no excess water 
was poured off and the lid of the wet chamber was opened for $4-5 \mathrm{~h}$ to allow for evaporation of excess water. The cultures were exposed to natural light for at least 8 hours a day. The first sporocarps of $C$. anomala were obtained on the 56 day of cultivation.

Microscopic examination was carried out with fresh preparations in $3 \% \mathrm{KOH}$ and distilled water. For microscopy, sporocarps were preserved as permanent slides in polyvinyl lactophenol.

\section{Morphological examination}

Initial morphological examination was performed using a Carl Zeiss Stemi DV4 stereomicroscope and a Carl Zeiss Axiolab E light microscope. Specimens were prepared for scanning electron microscopy using traditional SEM techniques, summarized as follows. Pieces of substrate bearing sporocarps were mounted on aluminum stubs using conductive adhesive tape. A gold coating was applied to the stubs in a vacuum evaporator. The specimens with metal coating were viewed and photographed using a Carl Zeiss EVO MA 10 scanning electron microscope.

Bark $\mathrm{pH}$ was measured with Biomer Nitron-pH pH-meter with Mettler Toledo InLab Surface combination electrode. Voucher specimens of the species are stored in the M.G. Popopv Herbarium (NSK), Novosibirsk, Russia. The nomenclature of myxomycetes follows Lado (2005-2018).

\section{Results}

Comatricha anomala Rammeloo, 1976, Bull. Jard. Bot. Belg. 46(1-2): 237.

Fig. 1.

DESCRIPTION: Sporocarps in groups, 1.5-2.5 mm total height, on a common hypothallus. Sporotheca is cylindrical, with a rounded wider base and rounded narrower top, dark brown. The stalk is $50-25 \%$ of the total height, not hollow, fibrous, black, almost opaque in transmitted light, rarely reddish-brown at the base. Hypothallus is common to the group, clearly visible, membrane-like, brown dark, mesh or folded, shiny at the base of the leg, yellowish-brown in transmitted light, with appendages in the form of stretching ropes. Columella is a continuation of the leg inside the sporangia, opaque, pointed at the top; it does not reach the end of the sporotecium and branches in the upper part into two or three main capillitium branches in the apical part. Peridium is rapidly destroyed and not preserved after maturation. Capillitum is dense and brown, forming a large-mesh surface net, which produces smaller individual meshes, up to 5 microns in diameter, on the periphery. Capillitium with many free endings up to $15 \mu \mathrm{m}$ long, with some up to $35 \mu \mathrm{m}$ long. Spore mass is brown. Spores are globose, light greyish-brown in transmitted light, 7.5-9 $\mu \mathrm{m}$ in diameter, ornamented with warts, some of which form 3-4 small areas of incomplete reticulum on the visible side of the spore with small meshes. Plasmodium is not observed.

DiSTRibution: Austria, Belgium, France, Germany, Italy, Norway, Malta, Portugal, Spain (Rammeloo 1976, Moreno et al. 1992, Johannesen 1984, Briffa et al. 2000, Neubert et al. 2000, GBIF 2018); California, USA (Kowalski \& Demaree 1987); Baja California, Mexico (Lizárraga et al. 1997); Cuba (Camino et al. 2008).

ECOLOGY AND HABITAT: Epiphyte. On bark folds of living trees. Previously isolated from bark of Jacaranda arborea, Salix cinerea, Quercus agrifolia, Quercus ilex, Crataegus monogyna, Nerium oleander, Eucalyptus globulus, Bacharis sp., Populus sp., Pinus halepensis (Neubert et al. 2000, Camino et al. 2008, GBIF 2019).

COLLECTIONS EXAMINED: RUSSIA, Novosibirsk Region, Iskitimsky district, vicinity of the village Novososedovo, coniferous pine forest with Populus tremula and Betula pendula, bark of Pinus sylvestris, $54.617331^{\circ} \mathrm{N}, 83.981728^{\circ} \mathrm{E}, 217 \mathrm{~m}$, substrate samples collected 2907 2017, A. Vlasenko \& V. Vlasenko, obtained in moist chamber culture 05 November 2018, A.Vlasenko (NSK 1026061).

COMMENTS: Comatricha anomala differs from other species of this genus in its unique warted spore ornamentation, with small areas of incomplete reticulum (Tab. 1). This is the only species in the Comatricha genus with the incomplete reticulum of spores. Studied sample differs from the type. It is characterized by spores $7.5-9 \mu \mathrm{m}$ in diameter, in original description spore size 9-10 $\mu \mathrm{m}$. 


\section{Table 1.}

Morphological comparison of Comatricha anomala and related species.

\begin{tabular}{|c|c|c|c|c|}
\hline Species & $\begin{array}{c}\text { Sporocarp } \\
\text { (colour, height, } \mathrm{mm} \text { ) }\end{array}$ & $\begin{array}{c}\text { Stalk } \\
\text { (proportion of } \\
\text { the total height) }\end{array}$ & $\begin{array}{c}\text { Spore } \\
(\text { size }, \mu \mathrm{m})\end{array}$ & $\begin{array}{c}\text { Spore ornamentation } \\
\text { (SEM) }\end{array}$ \\
\hline C. anomala & dark brown, 1.5-2.5 & $50-25$ & $7.5-9$ & $\begin{array}{c}\text { ornamented with warts, some } \\
\text { of which form } 3-4 \text { small areas } \\
\text { of incomplete reticulum on } \\
\text { the visible side of the spore } \\
\text { with small meshes }\end{array}$ \\
\hline C. afroalpina & dark brown, 1-2 & 50 & $8-10$ & $\begin{array}{l}\text { regularly verruculose with } \\
\text { dispersed groups of larger, } \\
\text { darker warts }\end{array}$ \\
\hline C. longipila & brown, 1.5-2 & 30 & $6.5-7$ & verruculose \\
\hline C. meandrispora & dark brown, 1-1.5 & $30-15$ & $5.5-7$ & $\begin{array}{l}\text { ornamentated with low, } \\
\text { thin, dark bands or strongly } \\
\text { broken reticulation, with } \\
\text { a few scattered, complete } \\
\text { small meshes which form a } \\
\text { characteristic irregular open } \\
\text { labyrinth }\end{array}$ \\
\hline C. reticulospora & dark brown, 2-2.5 & 30 & $6-10$ & $\begin{array}{l}\text { delicately reticulate with } \\
\text { c. } 6 \text { meshes on the visible } \\
\text { side of the spore }\end{array}$ \\
\hline C. subalpina & purplish brown, 1-2 & $50-30$ & $6-7$ & $\begin{array}{l}\text { with nearly complete, wavy, } \\
\text { banded reticulations }\end{array}$ \\
\hline C. vineatilis & dark brown, 1.5-2 & $50-30$ & $9-10$ & $\begin{array}{l}\text { very densely verruculose and } \\
\text { vaguely cluster-warted }\end{array}$ \\
\hline
\end{tabular}



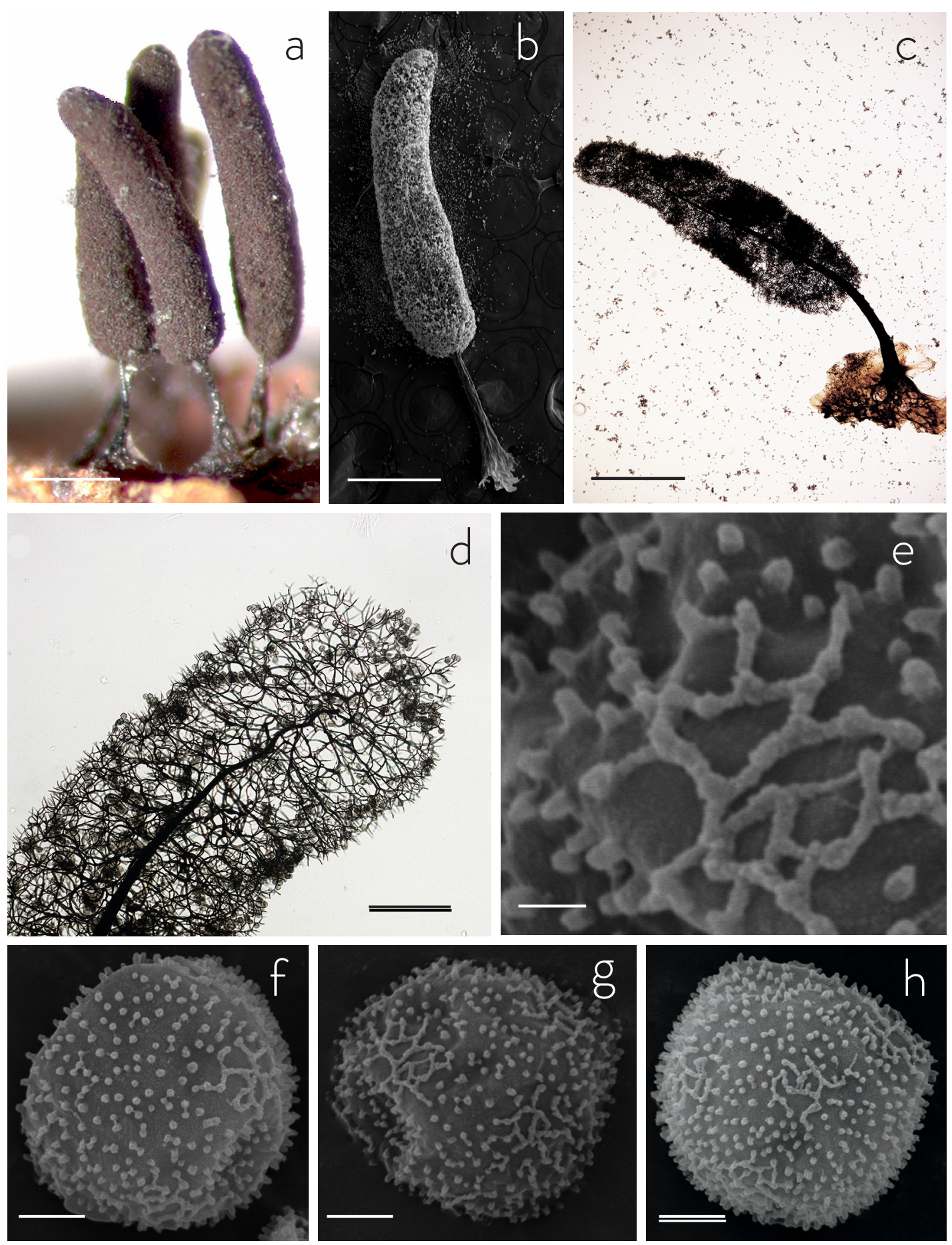

Fig. 1. Comatricha anomala. a: sporocarps in group, b: sporocarp (SEM), c: sporocarp (transmitted light), $\mathbf{d}$ : columella and capillitum (transmitted light), e: incomplete reticulum of spore (SEM), $\mathbf{f}, \mathbf{g}, \mathbf{h}$ : Spores (SEM). Scale bars: $\mathbf{a}, \mathbf{b}, \mathbf{c}=500 \mu \mathrm{m}, \mathrm{d}=100 \mu \mathrm{m}, \mathrm{e}=0.5 \mu \mathrm{m}, \mathrm{f}, \mathrm{g}, \mathrm{h}=2 \mu \mathrm{m}$. 


\section{Acknowledgements}

The work was carried out as part of a State Task to the Central Siberian Botanical Garden, the Siberian Branch of the Russian Academy of Sciences; project AAAA-A17-117012610055-3. Herbarium specimens from the Bioresources scientific collection (USU 440537) "Herbarium of higher vascular plants, lichens and fungi" (NSK) and equipment of The Core Facilities Center "Microscopic analysis of biological objects" of CSBG SB RAS were used.

\section{References}

Briffa, M., Moreno, G. \& Illana, C. 2000: Some rare Myxomycetes from Malta. Stapfia 73: 151-158.

Camino, M., Moreno, G., Castillo, A., Mitchell, D.W. \& Minter, D.W. 2008: Additions to the myxomycete biota of Cuba. 1. Mycotaxon 106: 75-102.

Fiore-Donno, A.M., Meyer, M., Baldauf, S.L. \& Pawlowski, J. 2008: Evolution of dark-spored Myxomycetes (slimemolds): Molecules versus morphology. Journal Molecular Phylogenetics and Evolution 46: 878-889.

Fiore-Donno, A.M., Kamono, A., Meyer, M., Schnittler, M., Fukui, M. \& Cavalier-Smith, T. 2012: 18S rDNA Phylogeny of Lamproderma and Allied Genera (Stemonitales, Myxomycetes, Amoebozoa). PLoS ONE 7(4), E35359.

GBIF 2017: https://www.gbif.org/species/8022980

(Date of access: 31.1.2019).

Gilbert, H.C. \& Martin, G.W. 1933: Myxomycetes found on the bark of living trees. Univ. lowa Stud. Nat. Hist. 15: 3-8.

Härkönen, M. 1977: Corticolous Myxomycetes in three different habitats in southern Finland. Karstenia 17: 19-32.

Härkönen, M. \& Ukkola, T. 2000: Conclusions on myxomycetes compiled of twenty-five years from 4793 moist chamber cultures. Stapfia 73: 105-112.

Johannesen, E. 1984: New and interesting Myxomycetes from Norway. Nordic journal of botany 4: 513-520.

Kowalski, D.T. \& Demaree, R.S. 1987: Comatricha anomala, a new record for the western hemisphere. Mycologia 67: 1218-1222.

Lado, C. 2005-2018: An on line nomenclatural information system of Eumycetozoa. Real Jardín Botánico, CSIC. Madrid, Spain. http://www.nomen.eumycetozoa.com (Date of access: 31.1.2019).
Lizárraga, M., Moreno, G. \& Illana, C. 1997: The Myxomycetes from Baja California (Mexico). I. Mycotaxon 63: 287-300.

Moreno, G., Illana, C. \& Heykoop, M. 1992: Spanish Myxomycetes. VI. Four interesting species belonging to Stemonitales. Cryptogamie Mycologie 13: 295-303.

Neubert, H., Nowotny, W., Baumann, K. \& Marx, H. Die 2000: Myxomyceten Deutschlands und des angrenzenden Alpenraumes unter besonderer Berücksichtigung Österreichs. Band 3: Stemonitales, 0-391.

Karlheinz Baumann Verlag, Gomaringen.

Novozhilov, Yu.K., Schnittler, M., Vlasenko, A.V. \& Fefelov, K.A. 2009: Myxomycete diversity of the Chuyskya depression (southern Altay Mts., Russia). Mikologiya i Fitopatologiya 43: 522-534.

Novozhilov, Yu.K., Schnittler, M., Vlasenko, A.V. \& Fefelov, K.A. 2010: Myxomycete diversity of the Altay Mts. (southwestern Siberia, Russia). Mycotaxon 111: 91-94.

Rammeloo, J. 1976: Comatricha anomala, a new Myxomycete from Belgium. Bulletin du Jardin Botanique National de Belgique 46: 237-240.

Vlasenko, A.V. 2013: Species diversity and taxonomic structure of myxomycetes of zonal and intrazonal biotopes of the plain territory of the south of Western Siberia (in Russian).

Rastitelnyy mir Aziatskoy Rossii 2: 3-11.

Vlasenko, A.V. \& Novozhilov, Yu.K. 2011: Myxomycetes of pine forests on the right bank of the Upper Ob region (in Russian). Mikologiya i Fitopatologiya 45: 465-477.

Vlasenko, A.V., Novozhilov, Yu.K. \& Vlasenko, V.A. 2013a: Myxomycetes of the steppe communities of the plain territory of the Altai Territory (in Russian). Vestnik Novosibirskogo gosudarstvennogo universiteta. Seria biologiya i klinicheskaya medicina 11: 5-12.

Vlasenko, A.V., Novozhilov, Yu.K., Vlasenko, V.A., Schepin, O.N., Morozova, Yu.A. \& Nikitina, A.A. 2013b: Species diversity and substrate specialization of myxomycetes of Strip pine forests of the Altai Territory (in Russian). Vestnik Novosibirskogo gosudarstvennogo universiteta. Seria biologiya i klinicheskaya medicina 11: 99-104.

Vlasenko, A.V., Novozhilov, Yu.K., Schepin, O.N. \& Vlasenko, V.A. 2016: Hydrochory as certain mode of distribution of myxomycetes along Floodlands in South of Western Siberia (in Russian). Mikologiya I Fitopatologiya 50: 14-23. 